\title{
GESTÃO SECRETARIAL: DELINEANDO ATIVIDADES, FUNÇÕES E COMPETÊNCIAS GERENCIAIS ${ }^{1}$
}

\author{
SECRETARIAL MANAGEMENT: DISCUSSION ABOUT THE ACTIVITIES, \\ FUNCTIONS AND POWERS MANAGERIAL
}

\section{GESTIÓN DE SECRETARIADO: DEBATE SOBRE LAS ACTIVIDADES, FUNCIONES Y ATRIBUCIONES GERENCIAL}

Conceição de Maria Pinheiro Barros, Doutoranda em Educação pela Universidade Estadual do Ceará (UECE). Endereço Profissional: Universidade Federal do Ceará (UFC), Rua Marechal Deodoro, 400 - Benfica, Fortaleza - CE - Brasil, CEP60020-060. Telefone: (85) 3366-7812. URL da Homepage: www.feaac.ufc.br.E-mail: conceicaompb@ufc.br

Joelma Soares da Silva, Mestre em Administração pela Universidade Estadual do Ceará (UECE). Endereço Profissional: Universidade Federal do Ceará (UFC), Rua Marechal Deodoro, 400 - Benfica, Fortaleza - CE - Brasil, CEP60020-060. Telefone: (85) 3366-7812.

URL da Homepage: www.feaac.ufc.br. E-mail: joelma.soares@ufc.br

Francisca Daniele Ferreira, Mestre em políticas públicas e gestão da educação superior pela Universidade Federal do Ceará (UFC). Endereço Profissional: Universidade Federal do Ceará, Rua Alexandre Barauna, 949, $1^{\circ}$ andar,Rodolfo Teófilo, Fortaleza, Ceará. Cep 60430-160.

Telefone: (85)3366 8001. URL da homepage: http://www.medicina.ufc.br. E-mail: danieleferreira_7@hotmail.com

\section{RESUMO}

O secretário executivo tem um perfil multifuncional, desenvolvendo uma visão abrangente do cotidiano secretarial e organizacional e um conjunto de atividades diversificadas que exigem conhecimentos de várias áreas. No que se refere à gestão secretarial, percebe-se o crescente interesse de estudos sobre o tema, entretanto, ainda existem lacunas relativas aos aportes teóricos e conceituais que possibilitem a consolidação da gestão Secretarial como teoria definida. Este trabalho tem como objetivo geral investigar as atividades, as funções, e as competências gerenciais necessárias à gestão secretarial, na percepção dos profissionais. Utilizou-se como metodologia um levantamento bibliográfico e uma pesquisa de campo do tipo qualitativa e descritiva. $\mathrm{O}$ instrumento de coleta de dados utilizado foi composto por um questionário contendo questões fechadas e abertas, ambas, contendo questões abertas com o intuito de obter maiores informações e detalhes acerca do tema estudado. O questionário foi fundamentado nas funções administrativas de Fayol (1990) e nas competências gerenciais apresentadas por Quinn et al. (2003) distribuídas nos oito papéis gerenciais, relacionando-as ao desempenho secretarial. O universo foi composto por 89 profissionais de Secretariado Executivo. Os dados objetivos foram tabulados e dispostos em tabelas por meio de frequência

\footnotetext{
${ }^{1}$ Artigo submetido em 18/02/2014, aceito em 28/03/2015 e divulgado em 31/12/2015 pelo Editor João Carlos Hipólito Bernardes do Nascimento, após double blind review.
} 
e as respostas abertas foram transcritas para análise. Utilizou-se a análise hermenêutica relacionando os resultados ao referencial teórico. Após a análise dos dados, inferiu-se que gestão secretarial pode ser compreendida como um processo administrativo que abrange atividades inerentes às funções, aos papéis e às competências de gerenciamento, principalmente, no âmbito das áreas de atuação do secretário executivo, o que denota uma limitação para o seu conceito.

Palavras-chave: Gestão Secretarial; Atividades de Gestão; Funções Administrativas; Competências Gerenciais.

\begin{abstract}
The Executive Secretary has a multifunctional profile, developing a comprehensive view of secretarial and organizational routine and a set of diverse activities that require expertise in several areas. Regarding to the management secretarial, one sees the growing interest in studies on this topic, but still gaps in the theoretical and conceptual contributions that enable the consolidation of the Secretariat as an area of knowledge. This paper has as main objective to investigate under the perception of professionals the roles and managerial skills that are necessary for the secretarial management. As an investigation method was used a literature and a field survey and qualitative and descriptive analyze was utilized. The data collection instrument was a questionnaire with options never often and always with open questions in order to get more information and details about the studied subject. The questionnaire was based on the administrative functions of Fayol (1990) and managerial skills presented by Quinn et. al. (2003) distributed in the eight managerial roles, serving as a secretarial performance. The universe was composed of 89 (eighty nine) Professional Executive Secretariat. We used the hermeneutic analysis relating the results to the theoretical framework. After analyzing the data it was inferred that secretarial management can be understood as an administrative process that includes activities related to the functions, the roles and powers of management mainly within the areas of the Executive Secretary, which denotes a limitation for your concept.
\end{abstract}

Keywords: Management Secretarial; Activities Management; Administrative Functions; Managerial Skills.

\title{
RESUMEN
}

El Secretario ejecutivo tiene un perfil multifuncional, el desarrollo de una visión integral de la rutina y de secretaría organizativa y un conjunto de actividades diversas que requieren conocimientos en varias áreas. En cuanto a la secretaría de gestión, se ve el creciente interés en los estudios sobre el tema, pero todavía hay lagunas en los aportes teóricos y conceptuales que permitan la consolidación de la Secretaría como una área de conocimiento. Este trabajo tiene como objetivo principal investigar las funciones y capacidades de gestión necesarias para la gestión secretarial, la percepción de los profesionales. Como metodología se utilizó como una revision de la literatura y una encuesta sobre el terreno de lo cualitativo y descriptivo. El instrumento de recolección de datos utilizado fue un cuestionario con opciones nunca y siempre con preguntas abiertas con el fin de obtener más información y detalles sobre el tema estudiado. El cuestionario se basa en las funciones administrativas de Fayol (1990) y las capacidades de gestión presentados por Quinn et al. (2003) distribuidos en los ocho puestos de dirección, que sirve como una actuación de secretaría. El universo estuvo constituido por 89 (ochenta y nueve) Secretaría Ejecutiva Profesional. Se utilizó el análisis hermenéutico relacionando los resultados con el marco teórico. Después de analizar 
los datos, se infería que la gestión secretarial puede ser entendida como un proceso administrativo que incluye actividades relacionadas con las funciones, las funciones y poderes de gestión, principalmente en las áreas de la Secretaría Ejecutiva, que denota una limitación para su concepto.

Palabras-clave: Gestión de Secretaría; Actividades de Gestión; Las Funciones Administrativas; Habilidades Directivas.

\section{INTRODUÇÃO}

profissional de Secretariado Executivo tem assumido maiores
responsabilidades no âmbito organizacional. Pesquisas científicas acerca de
temas que envolvem a sua atuação e formação (e.g OLIVRIERA, MORAES, 2014; PEREIRA, SILVA, 2014; SCHMIDT et al. 2008; MOURA 2008; GRANDO, CORREA, RINALDI, 2007) e objeto de estudo (e.g. HOELLER, 2006; NONATO JÚNIOR, 2009; SABINO, MARCHELLI, 2009; NASCIMENTO, 2012), emergem de forma crescente, o que fortalece a consolidação do campo secretarial na sociedade e nas ciências sociais. Um dos assuntos abordados é a gestão secretarial considerando-se que a evolução da área permeia um perfil que superou o tecnicismo levando-o ao desenvolvimento de diversas funções as quais esse profissional está apto a desenvolver. Entretanto, percebe-se a ausência de aportes teóricos e conceituais que possibilitem a consolidação da gestão secretarial como área de conhecimento.

Embora pesquisas na área tenham sido desenvolvidas (e.g. BECKER, CEOLIN, 2010, PORTELA, SCHUMACHER, 2009; SILVA; BARROS; BARBOSA, 2012), percebe-se a ausência de estudos que estabeleçam conceitos para o tema. Conforme Silva, Barros e Barbosa (2012, p. 123), "a Gestão Secretarial é um assunto importante para o Secretariado Executivo, no entanto, exige mais pesquisas na área, tanto teoricamente como empiricamente." Essa necessidade justifica-se pelas lacunas existentes a respeito dos aspectos conceituais relativos a esse modelo de gestão.

Ao considerar que as reflexões em torno da gestão secretarial perpassam os estudos sobre as atividades, as funções e as competências gerenciais necessárias a sua atuação, esta pesquisa tem como questão norteadora: quais são as atividades, as funções e as competências gerenciais necessárias ao desenvolvimento da gestão secretarial? Este trabalho tem como objetivo geral investigar as atividades, as funções e as competências gerenciais necessárias à gestão secretarial, na percepção dos profissionais de Secretariado Executivo e como objetivos específicos: a) identificar as principais atividades de gestão secretarial e sua abrangência nas organizações, b) analisar as funções administrativas na atuação do gestor secretarial; c) conhecer as competências necessárias para a atuação do secretário como gestor. Para o alcance dos objetivos propostos foi realizada uma pesquisa de natureza qualitativa e descritiva.

A investigação teve como teoria base as proposições de Fayol (1990) e Quinn et al. (2003). Para obtenção de informações sobre a temática, realizou-se uma pesquisa de campo direcionada aos profissionais da área. Considera-se a relevância desta pesquisa por contribuir para os debates acerca da gestão secretarial por meio dos aspectos teóricos e empíricos. Espera-se que os resultados alcançados apontem caminhos a serem trilhados em direção à consolidação e definição da gestão na área secretarial, considerada nesta pesquisa, como um processo em construção. 


\section{FUNDAMENTAÇÃO TEÓRICA}

\subsection{Gestão Secretarial: Reflexões Teóricas}

O secretário executivo tem um perfil multifuncional, desenvolvendo uma visão abrangente do cotidiano secretarial e organizacional e um conjunto de atividades diversificadas e que exigem conhecimentos de várias áreas, atividades estas repletas de imprevistos e que necessitam de soluções urgentes. No que se refere à gestão secretarial, percebe-se o crescente interesse de estudiosos da área em realizar pesquisa sobre essa temática. Dentre esses autores este trabalho destaca Bíscoli e Cielo (2004), Becker e Ceolin (2010), Silva, Barros e Barbosa (2012), Barros et al. (2013). Sobre a temática Bíscoli e Cielo (2004) afirmam que: "Ao secretário executivo, neste novo contexto cabe então o papel de gestor nas organizações em que atua, estando, assim apto a perceber, refletir, decidir e agir de maneira assertiva, pois a dinamicidade do mercado de trabalho não permite erros nem mesmo demora no processo de decisão".

Becker e Ceolin (2010, p. 10) complementam afirmando:

O reconhecimento do secretário, como sendo um profissional capacitado para o nível gerencial, é dado a partir do momento em que passou a exercer as suas funções baseado nas etapas de gerenciamento. Estando diretamente envolvido com os resultados da empresa, é notória a importância de conhecer e seguir o estilo processual de gestão.

Silva, Barros e Barbosa (2012) consideram que a gestão secretarial visualiza o secretário como um profissional que possui diversas habilidades e maiores responsabilidades no âmbito organizacional. As citadas autoras apontam os principais assuntos abordados nos estudos sobre o tema que fundamentam o seu conceito, distribuindo-os em cinco categorias: comportamento, gestão, políticas, formação secretarial e outros. Diante desses estudos, percebe-se que há uma evolução acerca do conceito de gestão secretarial, porém, ainda existem várias lacunas a serem preenchidas com relação à sua base teórica e conceitual. Nesse contexto, reflete-se: por que discutir aspectos teóricos em gestão secretarial? Percebe-se que, nos estudos sobre o tema, embora foquem nas práticas de gestão, as proposições ainda são incipientes. Há necessidade de apresentar alguma perspectiva sobre por que e como a gestão secretarial é praticada, visto que a teoria pode explicar como tornar a gestão em Secretariado mais eficaz para as organizações e para a sociedade. Para Lattimore et al. (2012), a teoria prediz a forma como as coisas acontecem apresentando a relação existente entre ações e eventos.

Considerando a assertiva de Bicudo (2011, p.13) ao considerar que a busca pela construção do conhecimento teórico "não se sustenta se o pensamento em processo for pautado por uma lógica linear", esta investigação corrobora com a percepção do Secretariado como uma área multidisciplinar e interdisciplinar fundamentando-se em Nascimento (2012), visto que esse profissional leva em consideração várias teorias ao desenvolver suas atribuições e tomar decisões sobre como podem contribuir para os objetivos organizacionais:

[..] não há um corpo teórico-metodológico bem definido para a área. Em outras palavras, não há teoria suficiente consolidada, nem um método de investigação próprio, com princípios delineadores.[...] historicamente, o secretariado é uma área de conhecimento que se vale de estudos teóricos de outras áreas, entre as quais a administração, a psicologia, a economia, a sociologia, a comunicação social e a lingüística (NASCIMENTO, 2012, p. 109) 
Diante do exposto, percebe-se a necessidade de respostas para questionamentos, como: O que é gestão secretarial? Quais são as atividades de gestão desenvolvidas pelo profissional de Secretariado? Quais são as competências do gestor secretarial? Qual é a área de abrangência dessa gestão? Algumas das perguntas que se faz no contexto da profissão de Secretariado em relação à gestão podem ser rotineiras, outras não. Lattimore et al. (2012) ponderam que quando alguém conhece a resposta para questões de rotina, tal pessoa tem uma visão de senso comum. Quando uma pessoa consegue responder de forma correta às questões que não são cotidianas, pode-se considerá-la como experiente. Entretanto, para que se responda a cada tipo de questionamento, o indivíduo deve compreender a existência de uma relação entre formas de atuação e acontecimentos. Nesse contexto, emerge a necessidade de teorias capazes de explicar essa relação. Uma teoria é conceituada por Lattimore et al. (2012, p. 59) como "[...] uma predição de como eventos e ações estão inter-relacionados".

Para Guarido Filho, Machado-da-Silva e Gonçalves (2010, p. 1) “A construção do conhecimento científico é um processo social caracterizado pela dinâmica recursiva entre as dimensões social e intelectual". Contudo, a despeito de sua delimitação teórica, é evidente que a Gestão Secretarial ainda carece de parâmetros norteadores. Tal realidade é compreensível considerando-se o fato de ser uma proposta relativamente recente e que ainda necessita de aprofundamento. Sob esta ótica, pesquisas sobre o tema apontam caminhos diversos comportando em seu bojo as mais amplas abordagens. Tal movimento encontra amparo na visão de Cabral (1998) ao afirmar que a pesquisa é cíclica e contínua e, portanto, nunca se completa, pois existem várias formas de pensar sobre um mesmo tema. $\mathrm{Na}$ esteira do pensamento do autor, Silva e Roman Neto (2010, p.83) afirmam que:

Os resultados de uma pesquisa suscitam questões adicionais que originam novas
pesquisas para ratificar, refutar ou complementar as "visões Construídas",
possibilitando o acúmulo de experiências e o avanço do conhecimento. Essa linha
de pensamento vai ao encontro da difusão de uma perspectiva multiparadigmática,
que permite uma visão circular pautada na contradição da convergência e na
complementaridade, fundamentais na construção de uma teoria.

O profissional de Secretariado pode ter conhecimento de diferentes teorias para tomar decisões adequadas para o desenvolvimento do seu trabalho. $\mathrm{O}$ valor que ele tem para a organização relaciona-se de forma direta à utilização dos conhecimentos teóricos no exercício da profissão. Sua atuação pode ser realizada por meio de consultoria, empreendedorismo, assessoria e gestão. Diante das diversas possibilidades do exercício dessa profissão, considera-se que nenhuma teoria responde sozinha a todos os questionamentos existentes em Secretariado Executivo. É importante um olhar para as teorias presentes no desenvolvimento das responsabilidades secretariais agrupando-as em suas diversas formas de atuação, segundo as suas possibilidades de utilização.

Na busca por delineamentos teóricos para a gestão secretarial, neste trabalho, o olhar está voltado para as teorias que contribuem para os aspectos administrativos na área. Dentre as diversas teorias que envolvem o processo de gestão, esta pesquisa tem como fundamentação as proposições de Fayol (1990) relativa às funções gerenciais e as proposições de Quinn et. al. (2003) que abordam as competências gerenciais. A partir dessa base teórica busca-se a relação existente entre essas prerrogativas e a atuação do gestor secretarial.

Este estudo corrobora com a compreensão de Nascimento (2012) acerca da necessidade de uma postura investigativa mais interacionista com relação às diferentes áreas do conhecimento de modo que se reflita sobre a utilização das teorias de áreas afins para além da sua aplicação aos problemas práticos secretariais e para consubstanciar a área como ciência, mas também para o desenvolvimento das áreas de forma dialógica. Mais do que valer-se das teorias de Fayol (1990) e de Quinn et. al. (2003), a pesquisa apresenta o 
norteamento para um possível construto na área secretarial e contribui para a validação das teorias utilizadas na amostra abordada.

\subsection{Funções Administrativas e Competências Gerenciais na Gestão Secretarial}

O processo administrativo proposto por Fayol (1990) fundamenta-se nos seguintes princípios: divisão do trabalho, disciplina, autoridade, unidade, hierarquia, centralização, remuneração justa, estabilidade dos funcionários, trabalho em equipe, iniciativa, interesse geral. A partir desse embasamento, Fayol (1990) destacou as obrigações atribuídas aos administradores na sociedade e definiu as funções dos gerentes. Na interpretação de Robbins, Judge e Sobral (2010) essas funções podem ser compreendidas da seguinte forma: planejamento: definição de metas, estratégias e o desenvolvimento de planos a fim de integrar e coordenar as atividades; organização: definição das tarefas a serem realizadas e estabelecimento de responsabilidades; direção: dirigir e coordenar as pessoas: monitoramento, comparação e possível correção das atividades. Com relação às funções administrativas na atuação secretarial, salienta-se que estas se fazem presentes na legislação de regulamentação (BRASIL, 1996), bem como nas Diretrizes Curriculares Nacionais para os cursos de graduação em Secretariado. No Art. $4^{\circ}$ da Resolução no 03, de 23 de junho de 2005 são definidas as competências e habilidades que os secretários devem apresentar após sua formação (BRASIL, 2005), corroborando para a definição do secretário como gestor ao ressaltar que a sua formação deve focalizar competências e habilidades que estão diretamente relacionadas ao processo administrativo.

Outro aspecto a ser considerado para a construção da identidade da gestão secretarial diz respeito às competências gerenciais na sua atuação. Conforme Fleury e Fleury (2001, p. 184), "competência é uma palavra do senso comum, utilizada para designar uma pessoa qualificada para realizar alguma coisa", nessa perspectiva, espera-se que o gestor secretarial possua qualificação gerencial para o desenvolvimento de suas atribuições nas organizações contemporâneas. Estudos sobre a profissão de Secretariado, Moura (2008), Cordeiro e Giotto (2008), Tagliari e Durante (2009), Barros, Braga e Silva (2011) e Barros et al. (2013), apontam competências necessárias à atuação desse profissional. Para Moura (2008, p. 29), "com a mudança de perfil e novas responsabilidades atribuídas ao profissional de secretariado, aumentou também a necessidade de formação e capacitação dessas profissionais".

As competências dos gerentes necessitam estar relacionadas com seus papéis no âmbito organizacional. Maximiano (2004) apresenta dez papéis gerenciais que se interrelacionam divididos em categorias: relações interpessoais, transferência de informações e tomada de decisões. Pesquisa sobre as semelhanças entre as competências gerenciais e secretariais revelou "que as competências necessárias para o desempenho da gestão são muito semelhantes tanto para os profissionais com formação em administração ou áreas afins como para os profissionais secretários executivos" (TAGLIARI; DURANTE, 2009, p. 41).

Buscando um delineamento das aptidões de gerenciamento necessárias à gestão secretarial, destacam-se as competências gerenciais definidas por Quinn et al. (2003), ao delinear os papéis gerenciais e suas respectivas competências, faz-se uma relação entre essas aptidões e a profissão de Secretariado Executivo. Quinn et al. (2003) descrevem as competências requeridas nos papéis: diretor; produtor, monitor, coordenador, facilitador, mentor, inovador e negociador. Ao desenvolver atividades de gestão em sua área de atuação, o secretário executivo deve ser capaz de desempenhar as funções gerenciais e suas competências. Sobre esse aspecto Barros et.al (2013, p. 44) consideram: 


\begin{abstract}
As competências gerenciais utilizadas na atuação do Secretário Executivo envolvem, principalmente, a compreensão de si mesmo e dos outros, a comunicação eficaz, a construção de equipes, a administração de informações por meio de pensamento crítico e a coordenação de projetos e/ou eventos. Estão presentes, ainda, na atuação secretarial: o planejamento e organização relativos aos serviços de secretaria; o estabelecimento de metas e objetivos relacionados ao trabalho em equipe; a administração do tempo e do estresse, além da contribuição nas negociações de acordos e compromissos, por meio da apresentação de ideias, sugestões e opiniões, para tomada de decisão em reuniões com pares e subordinados. Destacam-se, também, as competências relativas ao pensamento criativo ao buscarem a inovação dos processos de trabalho e convívio e gerenciamento da mudança.
\end{abstract}

Lima e Cantarotti (2010) ressaltam como competências secretariais: empreendedorismo, negociações, gerenciamento de informações, funções gerenciais como planejamento, organização, controle e direção, gestão secretarial e comunicação. Cordeiro e Giotto (2009) apresentam as competências complementares entre o profissional de secretariado executivo e o administrador. Considerando os conhecimentos, as habilidades e as atitudes desses profissionais, os citados autores afirmam que: “[...] o secretário executivo e o administrador, em suas rotinas diárias, têm colocado em prática competências afins, o que se deve a aspectos comportamentais ou habilidades pessoais que ambos têm em comum" (CORDEIRO; GIOTTO, 2008, p. 25).

Barros, Braga e Silva (2011) desenvolveram uma investigação acerca das competências gerenciais do profissional de Secretariado Executivo no nível estratégico. Como resultados, destacaram que a maioria dos investigados participa do planejamento estratégico, denotando que "[...] esse profissional vem conquistando, mais espaço no âmbito organizacional e os executivos conseguem reconhecer que para algumas decisões a participação do profissional de Secretariado Executivo é relevante" (BARROS, BRAGA; SILVA, 211, p. 100-101). A partir dessas considerações pode-se afirmar que o profissional de Secretariado desenvolve atribuições com foco na gestão.

\title{
3. PROCEDIMENTOS METODOLÓGICOS
}

Utilizou-se como metodologia um levantamento bibliográfico e uma pesquisa de campo do tipo qualitativa e descritiva. A pesquisa qualitativa caracteriza-se por descobrir as questões da investigação por meio da coleta de informações, sem necessariamente, utilizar a medição numérica para obter os dados (SAMPIERI; COLLADO; LÚCIO, 2006). O instrumento de coleta de dados utilizado foi o questionário com as opções nunca, frequentemente e sempre. Ressalta-se que foram propostas questões abertas com o intuito de obter maiores informações e detalhes acerca do tema estudado. Parasuraman (1991) explica que o questionário é um conjunto de questões, feito para gerar os dados necessários para se atingir os objetivos do estudo. A elaboração do instrumento foi fundamentada nas funções administrativas de Fayol (1990) e nas competências gerenciais apresentadas por Quinn et al. (2003), relacionando-as ao desempenho secretarial.

O universo foi composto por profissionais de Secretariado Executivo, tendo como critérios de seleção: a) ser graduado (a) em Secretariado Executivo; b) possuir experiência profissional em Secretariado; c) desenvolver atividades de gestão; d) acessibilidade aos respondentes. A pesquisa teve abrangência nacional com a participação de profissionais que atuam nas diversas áreas da esfera pública, da esfera privada e organizações nãogovernamentais. 
A amostra totalizou 89 participantes. Os questionários foram enviados por meio da ferramenta survey monkey, disponível na internet. A análise das informações coletadas foi fundamentada na teoria de Fayol (1990) e nas principais aptidões definidas por Quinn et al. (2003) relacionando-as ao desempenho secretarial. Utilizou-se a análise hermenêutica que, segundo Köller (2003), na pesquisa qualitativa tem o intuito de reconstruir os processos interativos de modo que produzam o "sentido prático" ou a construção social da realidade. Os procedimentos analíticos buscaram observar os princípios da interpretação hermenêutica objetiva de modo que contribuíssem para a validade da elaboração de resultados objetivos sobre o objeto estudado (WOHLRAB-SAHR, 2003).

\section{ANÁLISE DOS DADOS}

Os profissionais que contribuíram com a pesquisa, representados por $23,6 \%$, possuem idade entre 18 e 26 anos, $42,7 \%$ entre 27 e 34 anos, seguido de $23,6 \%$ entre 35 e 42 anos e $10,1 \%$ tem acima de 42 anos. Com relação ao sexo, a maioria, representada por $88,8 \%$ dos participantes desta pesquisa, é do sexo feminino. Quanto à formação, 46,1\% tem graduação, $41,6 \%$ possui especialização e $12,4 \%$ possui título de mestre. $37,1 \%$ dos profissionais trabalham na área há mais de 5 anos, seguidos de $25,8 \%$ entre 5 a 10 anos, $19,1 \%$ de 10 a 20 anos, e 13,5\% menos de 1 ano e 4,5\% mais de 20 anos. 50,6\% dos entrevistados trabalham em empresa privada, 46,1\% trabalham em empresa pública e 3,4\% atuam em organizações não-governamentais. A pesquisa abrangeu profissionais das diversas regiões do Brasil, a saber: $35,8 \%$ da região nordeste, $25,9 \%$ da região sudeste, $19,8 \%$ da região sul, $16,0 \%$ da região norte e $2,5 \%$ da região centro-oeste.

\subsection{As atividades de gestão e as funções administrativas do gestor secretarial a partir da teoria de Fayol}

Nesta fase, a pesquisa buscou identificar quais são as atividades de gestão bem como conhecer a dinâmica do processo administrativo na gestão secretarial. As atividades de gestão na atuação dos secretários citadas pelos investigados em ordem crescente estão sintetizadas na tabela a seguir, representadas pelo percentual de profissionais que as realizam. 
Tabela 1: Síntese das atividades de Gestão Secretarial.

\begin{tabular}{|c|c|c|c|}
\hline \multicolumn{4}{|c|}{ Atividades de gestão secretarial } \\
\hline \multicolumn{2}{|c|}{$\begin{array}{c}\text { Atividades de gestão secretarial que abrangem a } \\
\text { organização }\end{array}$} & \multicolumn{2}{|c|}{$\begin{array}{l}\text { Atividades de gestão secretarial que abrangem } \\
\text { a área de atuação dos profissionais }\end{array}$} \\
\hline Atividade & $\%$ & Atividade & $\%$ \\
\hline Gestão de documentos da organização. & $88,8 \%$ & $\begin{array}{l}\text { Planejamento e gestão da rotina } \\
\text { administrativa. }\end{array}$ & $85,4 \%$ \\
\hline Organização de eventos. & $62,9 \%$ & Gestão de informações. & $79,8 \%$ \\
\hline Planejamento de eventos da organização. & $47,2 \%$ & $\begin{array}{l}\text { Organização dos processos de trabalho } \\
\text { na área de atuação dos secretários. }\end{array}$ & $64,0 \%$ \\
\hline $\begin{array}{l}\text { Organização de processos e atividades da } \\
\text { instituição. }\end{array}$ & $44,9 \%$ & $\begin{array}{l}\text { Organização de atividades da área de } \\
\text { atuação dos secretários. }\end{array}$ & $62,9 \%$ \\
\hline $\begin{array}{l}\text { Participação no planejamento da } \\
\text { organização. }\end{array}$ & $36,0 \%$ & Gestão de materiais. & $60,7 \%$ \\
\hline $\begin{array}{l}\text { Participação na organização de métodos e } \\
\text { processos de trabalhos da organização. }\end{array}$ & $33,7 \%$ & Gestão de processos. & $59,8 \%$ \\
\hline $\begin{array}{l}\text { Participação na distribuição de atividades } \\
\text { dos funcionários da organização. }\end{array}$ & $28,1 \%$ & $\begin{array}{l}\text { Planejamento da área específica de } \\
\text { atuação secretarial. }\end{array}$ & $58,6 \%$ \\
\hline $\begin{array}{l}\text { Participação na avaliação do alcance dos } \\
\text { objetivos e metas organizacionais. }\end{array}$ & $19,1 \%$ & $\begin{array}{l}\text { Supervisão das atividades dos } \\
\text { funcionários da sua área de atuação. }\end{array}$ & $58,4 \%$ \\
\hline $\begin{array}{l}\text { Supervisão das atividades dos } \\
\text { funcionários. }\end{array}$ & $18,9 \%$ & $\begin{array}{l}\text { Distribuição de atividades dos } \\
\text { funcionários que atuam na área de } \\
\text { atuação secretarial. }\end{array}$ & $58,2 \%$ \\
\hline $\begin{array}{l}\text { Participação na avaliação do alcance dos } \\
\text { objetivos e metas organizacionais. }\end{array}$ & $18,7 \%$ & $\begin{array}{l}\text { Influenciar pessoas para o alcance de } \\
\text { objetivos. }\end{array}$ & $57,6 \%$ \\
\hline $\begin{array}{l}\text { Participação na avaliação de desempenho } \\
\text { dos funcionários. }\end{array}$ & $17,9 \%$ & $\begin{array}{l}\text { Liderar pessoas em sua área de } \\
\text { atuação. }\end{array}$ & $57,1 \%$ \\
\hline $\begin{array}{l}\text { Participação no controle de qualidade de } \\
\text { bens e serviços. }\end{array}$ & $17,6 \%$ & $\begin{array}{l}\text { Distribuição de atividades dos } \\
\text { funcionários que atuam na área de } \\
\text { atuação secretarial. }\end{array}$ & $56,8 \%$ \\
\hline \multirow[t]{2}{*}{ Outras } & \multirow[t]{2}{*}{$8,6 \%$} & $\begin{array}{l}\text { Acompanhamento do planejamento da } \\
\text { área de atuação secretarial. }\end{array}$ & $56,3 \%$ \\
\hline & & $\begin{array}{l}\text { Orientação de realização das } \\
\text { atividades secretariais. }\end{array}$ & $55,1 \%$ \\
\hline
\end{tabular}

Fonte: Elaborado pelas autoras.

Observa-se que as responsabilidades mencionadas referem-se às contribuições do secretário executivo para os objetivos da organização como um todo a partir da execução de atividades que abrangem tanto a sua área de atuação quanto a organização em seu contex to geral. A pesquisa revela que a gestão secretarial envolve as atividades inseridas nas áreas de atuação específicas de desempenho do secretário executivo tendo como base os quatro pilares funcionais da administração: planejar, organizar, liderar e controlar (FAYOL, 1990), por meio das competências gerenciais (QUINN et al., 2003).

As organizações possuem metas e objetivos a serem alcançados. O secretário executivo, por ser um facilitador da obtenção de resultados, deve desenvolver o processo administrativo em sua atuação visando contribuir para o alcance de objetivos e metas. Para que esses objetivos sejam desenvolvidos com êxito, faz-se necessário o bom desempenho das funções gerenciais. Sobre as funções gerenciais, Maximiano (2009, p.9) esclarece que "os processos administrativos são também chamados funções administrativas ou funções gerenciais." É fundamental entender que a administração é um processo que se constitui de outros processos ou funções e que este é o principal enfoque da abordagem funcional desenvolvida pelo estudo de Fayol (1990). 
Considerando-se que, na percepção de Maximiano (2009), o gestor é a pessoa que atua em uma organização por meio do planejamento, organização, direção e controle visando o alcance dos objetivos da empresa e que pessoas que geram qualquer conjunto de recursos são administradores, gerentes e gestores, independentemente da posição que ocupam, ou do título de seus cargos, pode-se inferir que o secretário executivo desempenha esse papel em sua área de atuação organizacional, qualificando-o como gestor secretarial, por meio do desenvolvimento de atividades que englobam as funções administrativas. As funções administrativas desenvolvidas por Fayol (1990) são: planejamento, organização, coordenação e controle. A pesquisa ora analisada denotou que todas essas atribuições estão presentes no cotidiano secretarial. A figura 1 apresenta uma síntese dessas funções na atuação do secretário executivo, a partir dos dados coletados nesta investigação:

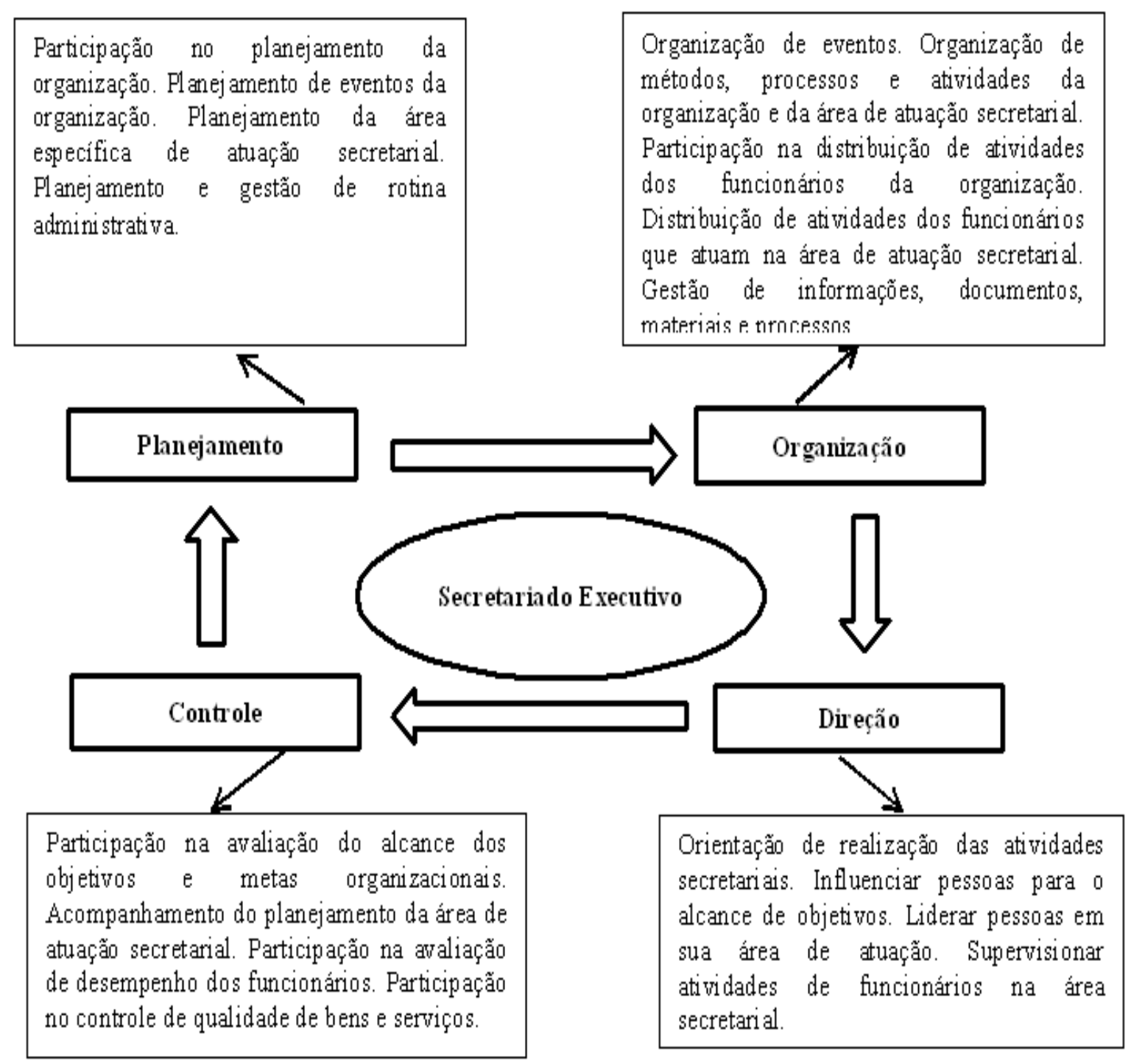

Figura 1: O processo administrativo em Secretariado Executivo.

Fonte: Elaborado pelas autoras a partir dos dados da pesquisa, fundamentando-se em Fayol (1990).

Conforme se observa na Figura 1, é possível se identificar diversas atividades secretariais que podem ser incluídas nas funções administrativas. O Planejamento pode ser 
desenvolvido na área secretarial a partir do estabelecimento de objetivos e/ou metas a serem alcançados nas atividades secretariais, bem como os meios mais adequados para a execução das atividades, utilizando-se os recursos disponíveis na organização. Para Maximiano (2009), o planejamento pode ser classificado em três tipos, de acordo com a abrangência nas organizações em: estratégico, tático ou funcional e operacional. É relevante que o secretário executivo elabore o planejamento de atividades sob sua responsabilidade no nível tático, operacional ou estratégico, dependendo da sua área de atuação e do nível hierárquico onde atua, desde que contribua para a estratégia organizacional.

$\mathrm{Na}$ função administrativa da organização, o secretário pode desenvolver métodos apropriados de melhor utilização dos recursos tangíveis e intangíveis capazes de levá-lo ao alcance dos objetivos e metas de sua área de atuação e da empresa, de acordo com o plano estratégico. Maximiano (2009, p. 8) traz a concepção de que "organização é o processo de dispor os recursos em uma estrutura que facilite a realização dos objetivos." Percebe-se que o processo de organização deve ser executado de modo a garantir a eficácia das tarefas. Ao desenvolver a função administrativa de direção, o profissional de Secretariado deve dar suporte para que as demais funções administrativas citadas nesse estudo (planejamento, organização e controle) possam ser efetuadas com sucesso. Essa função pode ser percebida na atuação secretarial por meio do elo existente entre a administração superior e os demais colaboradores, que é realizado pelo secretário. Além disso, a pesquisa denotou que o profissional de Secretariado desenvolve atividades de direção voltadas para os colaboradores da sua área de atuação.

Com relação à função controle, Maximiano (2009, p. 190) chama a atenção para o fato de que "controlar, em sua essência, é um processo de tomar decisões que tem por finalidade manter um sistema na direção de um objetivo, com base em informações contínuas sobre as atividades do próprio sistema e sobre o objetivo." Nessa perspectiva, o secretário executivo deve medir e corrigir o seu desempenho e dos seus pares com o intuito de garantir que os planos delineados para sua área de atuação e para a empresa sejam realizados. Observa-se que as funções administrativas de planejamento, organização, direção e controle estão interligadas entre si, possibilitando ao secretário executivo dar o direcionamento adequado para o desenvolvimento das suas atribuições.

\subsection{Competências gerenciais do secretário executivo na perspectiva de Quinn, Faerman, Thompson e McGrath}

Com o intuito de contribuir de forma empírica para as discussões acerca da gestão secretarial, essa fase da pesquisa de campo foi voltada aos profissionais de Secretariado Executivo, fundamentando-se nas competências gerenciais determinadas por Quinn et al. (2003). A análise sobre as competências gerenciais na atuação do secretário executivo foi fundamentada nas principais aptidões definidas por Quinn et al. (2003) distribuídas nos oito papéis gerenciais relacionando-as à gestão secretarial. A apresentação dos dados a seguir destaca os aspectos relativos às competências gerenciais necessárias à gestão em Secretariado, a partir das percepções dos profissionais secretários, considerando-se a soma dos percentuais das respostas indicadas como frequentemente e sempre.

As competências gerenciais necessárias ao secretário executivo no papel de mentor, a partir de Quinn et al. (2003) são: compreensão de si mesmo e dos outros, comunicação eficaz e desenvolvimento dos empregados. Com relação à competência compreensão de si mesmo e dos outros, 97,7\% dos profissionais afirmaram que procuram identificar as habilidades e as contribuições que cada colaborador pode oferecer para a organização ao desenvolver atividades com outras pessoas. $100 \%$ consideram-se capazes de perceber como as emoções afetam a si mesmos e aos outros. $100 \%$ dos secretários afirmaram que percebem e compreendem as reações específicas dos outros. 
Quadro 1: Competências do gestor secretarial - Papéis de mentor e facilitador.

\begin{tabular}{|c|c|c|}
\hline PAPEL & $\begin{array}{l}\text { COMPETÊNCIAS } \\
\text { GERENCIAIS }\end{array}$ & $\begin{array}{l}\text { CARACTERÍSTICAS DAS COMPETÊNCIAS } \\
\text { IDENTIFICADAS NA GESTÃO SECRETARIAL }\end{array}$ \\
\hline \multirow{3}{*}{ MENTOR } & $\begin{array}{l}\text { Compreensão de si } \\
\text { mesmo e dos outros }\end{array}$ & $\begin{array}{l}\text { - Identificar as habilidades e a contribuição que cada } \\
\text { colaborador pode oferecer para a organização ao } \\
\text { desenvolver atividades com outras pessoas. } \\
\text { - Perceber como as emoções afetam a si mesmo e aos } \\
\text { outros. } \\
\text { - Perceber e compreender as reações específicas dos } \\
\text { outros. }\end{array}$ \\
\hline & Comunicação eficaz & $\begin{array}{l}\text { - Transmitir o que sentem e pensam no ambiente de } \\
\text { trabalho. } \\
\text { - Ser um bom ouvinte. } \\
\text {-Colocar-se no lugar do outro no processo de } \\
\text { comunicação. }\end{array}$ \\
\hline & $\begin{array}{l}\text { Desenvolvimento dos } \\
\text { empregados }\end{array}$ & $\begin{array}{l}\text {-Delegar tarefas e responsabilidades aos outros } \\
\text { funcionários. } \\
\text { - Trocar informações, fatos, ideias e significados, usando- } \\
\text { os para informar, coordenar e motivar as pessoas. } \\
\text { - Reconhecer as realizações daqueles que desenvolvem } \\
\text { atividade, oferecendo feedback acerca das atividades } \\
\text { delegadas. }\end{array}$ \\
\hline \multirow{3}{*}{ FACILITADOR } & $\begin{array}{l}\text { Construção } \\
\text { equipes }\end{array}$ & $\begin{array}{l}\text { - Contribuir para a organização das atividades ao } \\
\text { desenvolver trabalho em equipe. } \\
\text { - Contribuir para a organização das atividades ao } \\
\text { desenvolver trabalho em equipe. } \\
\text { - Compartilhar informações. }\end{array}$ \\
\hline & $\begin{array}{l}\text { Processo decisório } \\
\text { participativo }\end{array}$ & $\begin{array}{l}\text { - Participar do processo de tomada de decisões da } \\
\text { organização e da sua área de atuação. } \\
\text { - Participar da tomada de decisão em reuniões com pares e } \\
\text { subordinados. }\end{array}$ \\
\hline & $\begin{array}{l}\text { Gerenciamento } \\
\text { conflitos }\end{array}$ & $\begin{array}{l}\text { - Administrar situações de conflitos no cotidiano do } \\
\text { ambiente de trabalho. } \\
\text { - Conhecer a existência do conflito e encarar a outra parte } \\
\text { para discutirem os sentimentos. }\end{array}$ \\
\hline
\end{tabular}

Fonte: Elaborado pelas autoras a partir dos dados da pesquisa, fundamentando-se em Quinn et al. (2003).

Percebe-se que, na gestão secretarial, os profissionais buscam desenvolver as competências requeridas dos papéis de mentor e facilitador. A compreensão de si mesmo e dos outros envolve a autocompreensão e fundamenta-se no modelo dos cinco fatores (grau de neurose, extroversão, receptividade a novas experiências, agradabilidade, conscienciosidade), no indicador de tipos de Myers-Briggs (introversão/extroversão, sensação/intuição e pensamento/ sentimento). Quanto à compreensão dos outros, é necessário que o gerente seja capaz de expandir a sua própria conscientização de tudo aquilo que menos deseja saber a seu próprio respeito (QUINN et al., 2003).

A respeito da comunicação, $95,4 \%$ dos participantes da pesquisa transmitem o que sentem e pensam no ambiente de trabalho. 98,9\% consideram-se um bom ouvinte. 98,9\% procuram se colocar no lugar do outro no processo de comunicação. A comunicação eficaz é entendida como o processo de comunicação que deve ser utilizado para informar, coordenar e 
motivar os colaboradores de forma eficaz, buscando dirimir os obstáculos na sua execução (QUINN et al., 2003). Considerando-se os aspectos destacados pelos secretários participantes percebe-se que há uma preocupação em possibilitar um ambiente adequado à comunicação interpessoal de forma eficaz.

De acordo com a pesquisa, os secretários realizam a delegação de tarefas e responsabilidades aos outros funcionários, representada por $87,1 \%$ dos participantes. $96,4 \%$ trocam informações, fatos, ideias e significados, usando-os para informar, coordenar e motivar as pessoas. A pesquisa com os secretários denotou que a maioria dos participantes, representada por $96,5 \%$, reconhece as realizações daqueles que desenvolvem atividade, oferecendo feedback acerca das atividades delegadas. A partir das considerações de Quinn et al. (2003) de que uma das abordagens de desenvolvimento dos empregados ocorre por meio da delegação, que visa ao aprimoramento das competências e habilidades dos colaboradores, infere-se que os secretários executivos investigados buscam contribuir para o crescimento participativo, gerencial profissional dos colaboradores por meio do compartilhamento de responsabilidades, da disseminação de informações e do reconhecimento das suas habilidades.

No papel de facilitador, o secretário executivo deve desenvolver as competências: construção de equipes, processo decisório participativo e gerenciamento de conflitos. Quanto a esse papel, $85 \%$ dos secretários destacaram como fundamental a realização de atividades de modo que contribua para a organização das atividades e facilite o trabalho em equipe. 56\% declararam que participam da tomada de decisões relativas à organização e $93 \%$ participam da tomada de decisões relativas à sua área de atuação, revelando que a tomada de decisão na gestão secretarial é realizada, principalmente, nas áreas específicas de Secretariado.

Outro aspecto ressaltado foi que $65,9 \%$ dos secretários afirmaram que participam da tomada de decisão em reuniões com pares e subordinados. Quanto à gestão de conflitos $87,2 \%$ administram situações de conflitos no cotidiano do trabalho. $77,9 \%$ procuram conhecer a existência do conflito e encarar a outra parte para discutirem os sentimentos. Fundamentando-se em Quinn et al. (2003) considera-se que, na gestão secretarial, os profissionais investigados, procuram construir equipes por meio do empenho de esforços para que um grupo de pessoas transforme-se em uma equipe de trabalho. Considerando-se a gestão participativa, os secretários têm a oportunidade de cooperar para decisões organizacionais, colaborando, essencialmente, para o processo de decisão em sua área de atuação. Isso proporciona aos colaboradores maior motivação e aumento de compromisso com a empresa. Além disso, foi destacada a administração de conflitos. No que diz respeito a esses aspectos deve-se observar que os conflitos podem apresentar consequências positivas ou negativas. Os gestores secretariais devem ter como foco a administração de conflitos de modo que possibilite o alcance de resultados positivos para a realização das atividades de secretaria e para a organização.

No papel de monitor, as competências destacadas por Quinn et al. (2003), são: administração de informações por meio do pensamento crítico, administração de sobrecarga de informações e administração dos processos essenciais. Sob esse aspecto obteve-se os seguintes resultados: $98,9 \%$ dos profissionais administram as informações recebidas por meio do pensamento crítico, 98,9\% procuram levar as informações úteis em consideração, 96,6\% procuram sustentar as afirmações e propostas de maneira sistemática e sucinta no ambiente de trabalho. Vale salientar que, na administração de informações por meio de pensamento crítico, as ideias devem ser apresentadas com clareza e conter o máximo de informações de forma crítica e objetiva numa linha de raciocínio lógico (QUINN et al., 2003).

Os secretários, representados por $96,5 \%$, ressaltaram que, ao trabalhar com processos, procuram os principais fatores que indicam o grau de eficácia de cada um. 97,7\% dos participantes procuram encaminhar os processos de forma eficaz e eficiente. Os dados denotam que o profissional de Secretariado necessita desenvolver a competência gerencial de 
monitor apresentada por Quinn et al. (2003). Como coordenador, o secretário pode desenvolver as competências indicadas por Quinn et al. (2003), a saber: gerenciamento de projetos, planejamento do trabalho e gerenciamento multifuncional. Os secretários participantes, representados por $77,6 \%$, declararam que realizam e/ou contribuem para o gerenciamento de projetos. $86,2 \%$ dos profissionais participam da realização de atividades, projetos e/ou eventos. Quanto ao planejamento das atividades, 96,4\% informaram que buscam agregar tarefas, responsabilidade e autonomia aos seus pares e subordinados e 89,4\% dos profissionais declararam que são responsáveis pelo fluxo de trabalho na sua área de atuação.

Quadro 2: Competências do gestor secretarial - Papéis de monitor e coordenador.

\begin{tabular}{|c|c|c|}
\hline PAPEL & $\begin{array}{l}\text { COMPETENCIAS } \\
\text { GERENCIAIS }\end{array}$ & $\begin{array}{c}\text { CARACTERÍSTICAS DAS } \\
\text { COMPETENCIAS IDENTIFICADAS NA } \\
\text { GESTÃO SECRETARIAL }\end{array}$ \\
\hline \multirow[t]{3}{*}{ MONITOR } & $\begin{array}{ll}\text { Administração } & \text { de } \\
\text { informações por meio do } \\
\text { pensamento crítico. }\end{array}$ & $\begin{array}{l}\text { - Gerir as informações recebidas por meio de } \\
\text { análise crítica. }\end{array}$ \\
\hline & $\begin{array}{l}\text { Administração de sobrecarga } \\
\text { de informações. }\end{array}$ & $\begin{array}{l}\text { - Levar as informações úteis em consideração. } \\
\text { - Sustentar as afirmações e propostas de } \\
\text { maneira sistemática e sucinta no ambiente de } \\
\text { trabalho. }\end{array}$ \\
\hline & $\begin{array}{l}\text { Administração dos processos } \\
\text { essenciais. }\end{array}$ & $\begin{array}{l}\text { - Procurar os principais fatores que indicam o } \\
\text { grau de eficácia de processo. } \\
\text { - Encaminhar os processos de forma eficaz e } \\
\text { eficiente. }\end{array}$ \\
\hline \multirow[t]{3}{*}{ COORDENADOR } & Gerenciamento de projetos. & $\begin{array}{l}\text {-Realizar e/ou contribuir para o gerenciamento } \\
\text { de projetos. } \\
\text { - Participar da realização de atividades, projetos } \\
\text { e/ou eventos. }\end{array}$ \\
\hline & Planejamento do trabalho. & $\begin{array}{l}\text { - Planejar agregando tarefas, responsabilidade e } \\
\text { autonomia aos seus pares e subordinados. } \\
\text { - Ser responsável pelo fluxo de trabalho na sua } \\
\text { área de atuação secretarial. }\end{array}$ \\
\hline & $\begin{array}{l}\text { Gerenciamento } \\
\text { multifuncional. }\end{array}$ & $\begin{array}{l}\text { - Coordenar atividades de um ou mais } \\
\text { funcionários. }\end{array}$ \\
\hline
\end{tabular}

Fonte: Elaborado pelas autoras a partir dos dados da pesquisa, fundamentando-se em Quinn et al. (2003).

Considerando-se que, de acordo com Quinn et al. (2003), o gerenciamento de projetos envolve o planejamento, definindo quais os pré-requisitos do trabalho, o volume de trabalho, os recursos de trabalho e o monitoramento de projetos, pode-se afirmar que os profissionais de Secretariado procuram coordenar as suas atividades, projetos e/ou eventos, bem como são os responsáveis pelo planejamento dessas atividades. Ressalta-se, ainda, que $55 \%$ dos secretários informaram que coordenam atividades de um ou mais funcionários, o que requer liderança e gerenciamento multifuncional. No gerenciamento multifuncional das equipes de trabalho as diretrizes básicas são: esclarecimento de metas e a declaração de missão, criação de massa crítica de liderança, manutenção da equipe por meio da responsabilidade do desempenho coletivo; manutenção da equipe multifuncional, fornecimento de informações relevantes, treinamento dos envolvidos e gerenciamento de processos (QUINN et al. 2003). 
Para o papel de diretor, as competências determinadas por Quinn et al. (2003), consideradas para atuação secretarial identificadas na pesquisa, são: planejamento e organização e estabelecimento de metas e objetivos. No papel de diretor, 93\% dos secretários afirmaram que elaboram o planejamento das atividades secretariais e $60 \%$ planejam e estabelecem prioridades na realização das atividades secretariais. Essas informações contribuem para a delimitação da gestão secretarial à áreas específicas de atuação no papel de Diretor, embora observe-se que os secretários, representados por $72,3 \%$, contribuem para o planejamento da organização. Salienta-se, ainda, que $74,7 \%$ dos secretários indicaram que participam da elaboração de objetivos e metas de trabalho em equipe.

Quadro 3: Competências do gestor secretarial - Papéis de diretor e produtor.

\begin{tabular}{|c|c|c|}
\hline PAPEL & $\begin{array}{l}\text { COMPETÊNCIAS } \\
\text { GERENCIAIS }\end{array}$ & $\begin{array}{l}\text { CARACTERÍSTICAS DAS COMPETÊNCIAS } \\
\text { IDENTIFICADAS NA GESTÃO SECRETARIAL }\end{array}$ \\
\hline & $\begin{array}{l}\text { Estabelecimento de } \\
\text { metas e objetivos. }\end{array}$ & - Elaborar objetivos e metas de trabalho em equipe. \\
\hline & $\begin{array}{l}\text { Planejamento e } \\
\text { organização. }\end{array}$ & $\begin{array}{l}\text { - Contribuir para o planejamento da organização. } \\
\text { - Elaborar o planejamento das atividades secretariais. } \\
\text { - Planejar e estabelecer prioridades na realização das } \\
\text { atividades secretariais. }\end{array}$ \\
\hline DIRETOR & $\begin{array}{l}\text { Desenvolvimento dos } \\
\text { empregados. }\end{array}$ & $\begin{array}{l}\text { - Delegar tarefas e responsabilidades aos outros } \\
\text { funcionários. } \\
\text { - Trocar informações, fatos, ideias e significados, usando- } \\
\text { os para informar, coordenar e motivar as pessoas. } \\
\text { - Reconhecer as realizações daqueles que desenvolvem } \\
\text { atividade, oferecendo feedback acerca das atividades } \\
\text { delegadas. }\end{array}$ \\
\hline \multirow{3}{*}{ PRODUTOR } & Trabalho produtivo. & $\begin{array}{l}\text { - Desenvolver as atividades procurando identificar os } \\
\text { problemas que impedem o alcance dos objetivos e metas. }\end{array}$ \\
\hline & $\begin{array}{l}\text { Fomento a um } \\
\text { ambiente de trabalho } \\
\text { produtivo. }\end{array}$ & $\begin{array}{l}\text { - Deixar-se preocupar, fascinar e envolver pelas atividades } \\
\text { que realizam. } \\
\text { - Produzir e mobilizar pessoas e recursos para conseguir } \\
\text { que as coisas sejam realizadas. }\end{array}$ \\
\hline & $\begin{array}{l}\text { Administração do } \\
\text { tempo e do estresse/ } \\
\text { equilíbrio de } \\
\text { demandas } \\
\text { concorrentes. }\end{array}$ & $\begin{array}{l}\text { - Analisar e administrar as atividades. } \\
\text { - Analisar regularmente a maneira como está utilizando o } \\
\text { tempo no ambiente de trabalho. } \\
\text { - Administrar o tempo para as atividades de curto e longo } \\
\text { prazo. }\end{array}$ \\
\hline
\end{tabular}

Fonte: Elaborado pelas autoras a partir dos dados da pesquisa, fundamentando-se em Quinn et. al (3003).

O planejamento e a organização são fundamentados na visão e estratégia articuladas (QUINN et al., 2003) que devem ser observadas pelo gestor secretarial. No que se refere ao estabelecimento de metas e objetivos o gerente participa da formulação de objetivos específicos, com vistas à consecução da visão; definição de metas nos diversos níveis da organização; bem como da estratégia (QUINN et al., 2003). Percebe-se que, no papel de diretor, os profissionais de Secretariado necessitam envolver-se com o planejamento de sua área e da organização como um todo. Conforme Quinn et al. (2003), o papel de produtor complementa o papel de diretor. $\mathrm{Na}$ atuação secretarial foram destacadas as competências: 
trabalho produtivo, fomento a um ambiente de trabalho produtivo e a administração do tempo e do estresse/ equilíbrio de demandas concorrentes. $O$ trabalho produtivo envolve a definição de metas, engajamento total e imersão na atividade, hipersensibilidade e consciência da atividade durante seu desenrolar e capacidade de desfrutar da experiência imediata, em tempo real (QUINN et al., 2003). A esse respeito, salienta-se que 95,4\% dos secretários consideram o desenvolvimento de suas atividades procurando identificar os problemas que impedem o alcance dos objetivos e metas.

$\mathrm{O}$ fomento a um ambiente de trabalho produtivo refere-se ao sistema de recompensa na nova economia e a motivação dos outros (QUINN et al, 2003). Quanto ao ambiente de trabalho produtivo, 88,4\% dos participantes destacaram a importância de se preocupar, fascinar e envolver pelas atividades que realizam. Esse aspecto pode aumentar a motivação para as suas obrigações na empresa. $97,7 \%$ dos profissionais consideraram que possuem capacidade de produzir e de mobilizar pessoas e recursos para que as coisas sejam feitas. Os aspectos relacionados à gestão do tempo ressaltados pelos investigados envolvem a análise e a administração das atividades. 94,3\% analisam regularmente a maneira como estão utilizando o tempo no ambiente de trabalho e 95,5\% dos secretários administram o tempo para as atividades de curto e longo prazo. Com relação à administração do tempo e do estresse/ equilíbrio de demandas concorrentes, considera-se que o estresse afeta a saúde física dos colaboradores bem como reduz a motivação e a capacidade de relacionar-se com os colegas, além dos prejuízos para as organizações. Fundamentando-se em Quinn et al. (2003) pode-se afirmar que para gerir o tempo com eficiência é importante que os secretários utilizem estratégias, como planejamento e estabelecimento de prioridades a fim de utilizar o tempo de forma eficiente.

No papel de negociador, pondera-se que a competência a ser desenvolvida para contribuir com as responsabilidades da área secretarial, a partir das aptidões citadas por Quinn et al. (2003), são: a negociação de acordos e compromissos e apresentação de ideias. A negociação de acordos e compromissos se refere a capacidade de manter o diálogo com o intuito de solucionar divergências mediante cuidadoso compartilhamento de pontos de vista (QUINN et al., 2003). Sob esse aspecto, 86,2\% dos investigados informaram que contribuem para a negociação de acordos e compromissos da organização por meio da apresentação de ideias, sugestões e opiniões.

Quanto ao papel de inovador, percebe-se que a atuação secretarial necessita de criatividade e acompanhamento das mudanças remetendo às aptidões ressaltadas por Quinn et al. (2003): convívio e gerenciamento da mudança e pensamento criativo. O convívio com a mudança trata da aceitação pessoal e do convívio com a mudança. Para o gerenciamento da mudança é necessário ser flexível às transformações visando alcançar os objetivos e metas organizacionais. Existem cinco tipos de mudanças capazes de provocar a resistência dos funcionários: mudanças que afetem as demandas de conhecimento e competência, mudanças associadas a perdas econômicas ou de status, mudanças sugeridas por outros, mudanças que envolvam riscos e mudanças que acarretem ruptura das relações sociais (QUINN et al, 2003). Os investigados, representados por $80 \%$, destacaram que possuem facilidade em conviver e contribuir para os processos de mudanças organizacionais e $91,9 \%$ dos participantes procuram influenciar o fluxo de energia e recursos disponíveis reservados para determinadas metas. 
Quadro 4: Competências do gestor secretarial - Papéis de negociador e inovador.

\begin{tabular}{|c|l|l|}
\hline \multicolumn{1}{|c|}{ PAPEL } & $\begin{array}{l}\text { COMPETENCIAS } \\
\text { GERENCIAIS }\end{array}$ & \multicolumn{1}{c|}{$\begin{array}{c}\text { CARACTERÍSTICAS DAS COMPETENCIAS } \\
\text { IDENTIFICADAS NA GESTÃO SECRETARIAL }\end{array}$} \\
\hline \multirow{5}{*}{ NEGOCIADOR } & $\begin{array}{l}\text { Negociação de } \\
\text { acordos, } \\
\text { compromissos e } \\
\text { apresentação de } \\
\text { ideias. }\end{array}$ & $\begin{array}{l}\text { - Contribuir para a negociação de acordos e compromissos } \\
\text { da organização por meio da apresentação de ideias, } \\
\text { sugestões e opiniões. }\end{array}$ \\
\hline \multirow{5}{*}{ INOVADOR } & $\begin{array}{l}\text { Convívio } \\
\text { gerenciamento da } \\
\text { mudança. }\end{array}$ & $\begin{array}{l}\text { - Possuir facilidade em conviver e contribuir para os } \\
\text { processos de mudanças organizacionais } \\
\text { - Influenciar o fluxo de energia e recursos disponíveis } \\
\text { reservados para determinadas metas. }\end{array}$ \\
\cline { 2 - 4 } & $\begin{array}{l}\text { Pensamento criativo. } \\
\text { - Inovar os processos de trabalho por meio do pensamento } \\
\text { criativo. } \\
\text { - Colaborar para a criatividade e inovação ao expor suas } \\
\text { ideias de modo a contribuir para o alcance das metas. }\end{array}$ \\
\hline
\end{tabular}

Fonte: Elaborado pelas autoras a partir dos dados da pesquisa, fundamentando-se em Quinn et. al. (2003).

O pensamento criativo é concernente à forma de pensar que envolve a geração de novas ideias e soluções, destacando-se três dimensões: habilidades referentes ao domínio, habilidades criativas e motivação de tarefas (QUINN et al., 2003). Nessa linha de pensamento, $65 \%$ dos secretários ressaltaram que procuram inovar os processos de trabalho por meio do pensamento criativo. 94,2\% dos secretários colaboram para a criatividade e inovação ao expor suas ideias de modo a contribuir para o alcance das metas.

A partir dos dados e análise teórica da pesquisa foi possível delinear as competências e seus respectivos aspectos necessários ao desenvolvimento das atividades de gestão secretarial. O quadro abaixo sintetiza as atividades, os papéis, as competências gerenciais e os aspectos relativos à gestão secretarial apresentados pelos profissionais da área, nesta investigação, tendo como fundamentação as proposições de Quinn et al. (2003). Conforme informações destacadas no quadro 2, as responsabilidades de gestão desenvolvidas pelos profissionais que participaram da investigação inserem-se nos papéis de gerenciamento propostos por Quinn et al. (2003) e, por conseguinte, exigem do secretário executivo o desenvolvimento de competências gerenciais relativas a cada um desses papéis. Nessa linha de pensamento, considera-se que a gestão secretarial é um desafio emergente para os profissionais da área.

\subsection{Buscando uma delimitação para a atuação do gestor secretarial}

Esta fase da pesquisa destinou-se a investigar e delimitar a área de abrangência da gestão secretarial. O questionamento a ser respondido era: "As atribuições de gestão que você desenvolve têm como abrangência a organização como um todo ou sua área de atuação? Como isso ocorre?" Das respostas encontradas 44 dizem que contemplam sua área de atuação; 18 afirmam que suas atribuições abrangem toda a organização; 10 expressam que suas atividades agregam as duas abrangências, ou seja, começam em sua área de atuação, mas os resultados acabam por repercutir em toda a organização e 14 não souberam definir. Dessa forma, pode-se destacar a distinção feita por alguns profissionais, em três níveis de atuação da gestão secretarial: o primeiro abrange a área de atuação específica de Secretariado, o segundo comentário abrange toda a organização e o terceiro abrange tanto a área específica de atuação como a organização como um todo:

[...] limitam-se a minha área de atuação. Não ocorre um aproveitamento maior das percepções e ações da secretária que, por se relacionar com todas as áreas, tem visão abrangente (SECRETÁRIO 8). 
A organização como um todo; moldo as ações às necessidades especificas quando se faz necessário (SECRETÁRIO 30).

As atribuições de gestão que desenvolvo têm abrangência na área em que atuo, mas que reflete no resultado final da Unidade a qual trabalho (SECRETÁRIO 32).

Identificando as competências gerenciais classificadas por Quinn et al. (2003), no papel de mentor, que tem como aspectos principais a compreensão de si mesmo e dos outros, a comunicação eficaz e o desenvolvimento dos empregados, cita-se que isso ocorre por meio da exposição de "opiniões e ideias, como também pesquisando a opinião de todos para um melhor desempenho da organização" (SECRETÁRIO 35). Verifica-se, na opinião do entrevistado, a capacidade de comunicação que a empresa proporciona, bem como a iniciativa do próprio pesquisado em transmitir o que sente e pensa no ambiente de trabalho, buscando a troca de informações e ideias para reconhecer, coordenar e motivar a participação dos colaboradores da instituição.

Outro aspecto importante da gestão secretarial é o papel de facilitador, também identificado na fala do Secretário 35. Fundamentando-se em Quinn et al. (2003), neste papel, o secretário facilitador deve construir equipes coesas, participativas, compartilhando informações para a tomada de decisões da organização, administrar conflitos, quando houver. O modelo dos processos internos engloba os papéis de monitor e coordenador. Como monitores, os secretários executivos devem saber o que se passa em sua instituição, determinar se as pessoas estão cumprindo as regras e averiguar se a unidade está fazendo sua parte. O papel de monitor requer cuidado com detalhes, controle e análise. Como coordenadores, espera-se que se dê sustentação à estrutura e ao fluxo do sistema. As características comportamentais do coordenador incluem a organização, a coordenação dos esforços da equipe, o enfrentamento de crises e a logística. A função afim, portanto, do secretário é a de se tornar um monitor tecnicamente competente e um coordenador confiável. Fato que se encontra nas respostas:

De um modo amplo a organização como um todo, pois trabalho em um setor-chave da organização. Certamente na minha área de atuação a abrangência é mais especifica, pois é a base da eficiência dos resultados. Procuro sempre planejar, organizar, dirigir e controlar as ações, a fim de que a gestão atinja a eficácia (SECRETÁRIO 60)

Tem como abrangência a organização como um todo, pois gerencio um grupo de nove profissionais de diferentes áreas que juntos buscam a excelência na Gestão de Segurança, Saúde e Meio Ambiente. Além dessa gestão (pessoal e técnica) realizo atividade de acompanhamento financeiro do contrato (SECRETÁRIO 70)

No modelo de competências gerenciais desenvolvido por Quinn et al. (2003), encontram-se os perfis de diretor e produtor. Os diretores devem explicitar expectativas por meio de processos, tais como planejamento e delimitação de metas. Já os produtores são orientados para tarefas, mantêm o foco no trabalho e exibem alto grau de interesse, motivação, energia e ímpeto pessoal. Tal modelo tem como objetivos a produtividade e o lucro. A função, portanto, é tornar-se um diretor que decide e um produtor pragmático. Identifica-se na afirmação do Secretário 1, o perfil de diretor é contemplado em suas atividades secretariais, observa-se:

[...] atuei em diversas situações com poder de decisão, além de participar de reuniões com poder de decisão, acompanhar projetos e solucionar conflitos nos setores da empresa[...]administrava funcionários particulares [...] (SECRETÁRIO 1). 
Já na assertiva do Secretário 39, percebe-se que se esse profissional se identifica com papel de produtor, tendo em vista que este complementa o papel de diretor, sendo destacados o trabalho produtivo, administração do tempo e o equilíbrio de demandas concorrentes:

As minhas atribuições de gestão estão voltadas para área em que atuo. Planejo e gerencio as atividades relativas aos serviços de secretaria. Gerencio o controle de documentação. Participo do planejamento das atividades e metas da minha unidade (SECRETÁRIO 39).

Na sequência dos papéis gerenciais, Quinn et al. (2003) completa os oito perfis como inovadores e negociadores. Os inovadores costumam ser visionários; nesse papel, o gerente é encarregado de facilitar a adaptação e a mudança, identificar tendências significativas e tolerar as incertezas e os riscos. Os negociadores preocupam-se com a sustentação da legitimidade exterior e a obtenção de recursos externos; devem ter astúcia política, poder e capacidade de persuadir e influenciar. Tais perfis preenchem a necessidade de compreender e administrar um mundo em rápida transformação e no qual o conhecimento é intenso. Os processos fundamentais são a adaptação política, resolução criativa de problemas, inovação e gerenciamento das mudanças. O secretário executivo deve se tornar um inovador criativo e um negociador que usa o seu poder de influenciar na organização. O relato do Secretário 1 engloba perfeitamente estes dois perfis e é citado para um melhor entendimento:

[...] fui responsável pelas atividades direcionadas para as rotinas de contratos, finanças e compras, como: análise e aprovação de contratos, para posterior assinatura do Diretor, controle da conta corrente da empresa e aprovação dos pedidos de compra. Na penúltima empresa secretariava e respondia diretamente a Diretoria Comercial, Financeira e Administrativa. Atuei nas negociações de valores cambiais, fretes internacionais, desembaraços aduaneiros e fechamento de câmbio [...] fui responsável pela criação do endomarketing, provando a criação de mídias, materiais promocional, brindes, campanhas, anúncios, comerciais, além de padronizar a identidade, reforçar e valorizar a marca, gerando um padrão de comunicação com os clientes internos e externos. [...] (SECRETÁRIO 1).

Vê-se que muito dos perfis gerenciais já são contemplados nas atividades diárias dos secretários executivos. $\mathrm{O}$ fazer gerencial é cada vez mais encontrado nos perfis profissionais atuantes nas empresas. Porém, ainda há óbices em alguns setores, provocados pela burocracia e falta de conhecimento do potencial do profissional de Secretariado Executivo, como fica claro nos depoimentos abaixo:

[...] em uma instituição pública a gestão fica a cargo do coordenador ou do diretor (SECRETÁRIO 2).

[...] trabalho em uma associação de classe e, quase sempre, devido à política da entidade, os funcionários não têm autonomia ou liberdade para tomadas de decisões, desde as mais simples às mais complexas (SECRETÁRIO 10).

Outros participantes concordam com essa percepção, conforme se observa a seguir:

Geralmente abrange minha área de atuação somente, pois, o trabalho é bem divido em etapas entre outros colaboradores (SECRETÁRIO 21).

Tenho autonomia para desenvolver as atividades relacionadas á minha área de atuação (SECRETÁRIO 33).

Apenas na área em que atuo. Cada Secretária é responsável pela gestão de fluxo de documentos da sua área (SECRETÁRIO 37).

Somente à minha área de atuação, pois a organização é muito grande e meu cargo é limitado às atividades de meu local de trabalho (SECRETÁRIO 41).

As minhas atribuições de gestão estão voltadas para a área em que atuo. Planejo e gerencio as atividades relativas aos serviços de secretaria. Gerencio o controle de documentação. Participo do planejamento das atividades e metas da minha unidade (SECRETÁRIO 43). 
Os profissionais de Secretariado precisam adquirir diferentes competências para galgar outros patamares na organização. Assim, para ser um gestor, é preciso não só habilidade para desempenhar os oito papéis mencionados, mas também que tenha condições de mesclar e equilibrar os diferentes papéis, observando a abrangência de sua atuação. Pode-se inferir que o secretário executivo, no âmbito da organização, executa as funções gerenciais e desenvolvem a função de gestor, conforme a visão de Fayol (1990) ao considerar que as funções administrativas não são responsabilidade exclusiva da diretoria e presidência, mas está distribuída por todos os níveis hierárquicos da organização. A análise possibilita a percepção de que, mesmo que a abrangência e a influência do desempenho das funções gerenciais executadas pelos secretários participantes desta pesquisa estendam-se à sua área de atuação ou à organização como um todo o processo administrativo de Fayol (1990) está presente no exercício do profissional de Secretariado Executivo, caracterizando-o como gestor das atribuições de secretária.

\section{CONSIDERAÇÕES FINAIS}

A realização deste trabalho possibilitou o delineamento de algumas reflexões acerca das atividades, funções e competências gerenciais necessárias à gestão secretarial, bem como a sua abrangência nas organizações contemporâneas. Considerou-se que a base teórica em Secretariado envolve o diálogo com outras áreas de conhecimento, não tendo uma teoria que englobe a complexidade de sua atuação. Salienta-se que o fato de se ponderar o conhecimento secretarial como multidisciplinar e interdisciplinar, não a desqualifica para sua consolidação como área científica. As atribuições concernentes à gestão secretarial identificadas nesta investigação relacionam-se às funções administrativas. Foram destacados pelos participantes o desenvolvimento de atividades de gestão que abrangem a organização em seu contexto geral e a área específica secretarial. Quanto às funções gerenciais, percebeu-se a presença do processo administrativo na área específica do cotidiano do trabalho do secretário executivo, por meio da gestão das atividades secretariais, distribuindo-se as suas atividades em: planejamento, organização, direção e controle.

Ao averiguar quais são as competências gerenciais fundamentais para o desenvolvimento das atividades de gestão secretarial foram evidenciados os papéis gerenciais e as respectivas competências a serem desenvolvidas pelos secretários executivos investigados. As competências gerenciais relativas às atribuições de gestão secretarial salientadas pelos profissionais que participaram desta pesquisa foram distribuídas nos papéis mentor, facilitador, coordenador, monitor, diretor, produtor, negociador e inovador.

O estudo possibilitou conhecer a amplitude dessas responsabilidades buscando uma delimitação para a sua abrangência no âmbito organizacional. Sob esse aspecto foram delineados três níveis de atuação da gestão secretarial: área de atuação específica de Secretariado, a organização como um todo e uma mescla das duas abrangências. Vale salientar que existe uma predominância do desempenho secretarial na sua área específica. No entanto, as ações desse profissional, segundo a opinião dos participantes, são refletidas nos resultados da organização de forma holística.

Essas atividades, abrangência e competências apontam para a existência de novos desafios a serem superados pelos profissionais de Secretariado Executivo, visando uma atuação capaz de contribuir de forma crescente para o alcance de metas e objetivos da organização por meio do desenvolvimento de atividades que envolvem a gestão em Secretariado. Salienta-se que as aptidões delineadas nesta pesquisa têm como principal lócus de atuação a gestão dos serviços de secretaria, considerando-se a área de atuação dos 
profissionais investigados de forma que colaborem para o desempenho da organização como um todo.

Assim sendo, pode-se inferir que a gestão secretarial pode ser compreendida como um processo administrativo que abrange atividades inerentes às funções, aos papéis e às competências de gerenciamento, principalmente, no âmbito das áreas de atuação do secretário executivo, o que denota uma limitação para o seu conceito. As reflexões em torno do conceito de gestão secretarial são recentes e requerem estudos teóricos e empíricos visando à consolidação da área. Nessa perspectiva, considera-se que esta pesquisa contribui para as discussões acerca do tema, por ter como resultado delineamentos sobre as atividades, a abrangência e as competências gerenciais a serem desenvolvidas na gestão secretarial e por apontar caminhos a serem explorados e aprofundados em direção ao preenchimento das lacunas existentes em torno da definição de gestão secretarial.

\section{REFERÊNCIAS}

BARROS, Conceição de Maria Pinheiro; BRAGA, Maisa Cruz; SILVA, Joelma Soares da. As competências gerenciais na atuação do secretário executivo no nível estratégico. Revista Expectativa, n. 1, p. 91-106, jan./dez. 2011. Disponível em: http://erevista.unioeste.br/index.php/expectativa/article/view/6096. Acesso em: 2 fev. 2013.

BARROS, Conceição de Maria Pinheiro; SILVA, Joelma Soares da; LIMA, Geovana Alves de; BRITO, Daniela Graciela Silva. As competências gerenciais desenvolvidas pelos secretários executivos. Revista de Gestão e Secretariado. São Paulo, n. 2, p 25-47, jul./dez. 2013. Disponível em: http://revistagesec.org.br/ojs-

2.3.8/index.php/secretariado/article/view/131\#.UveFf_ldVAA. Acesso em: 7 fev. 2014.

BECKER, Graciel; CEOLIN, Jamara Ceolin. Gestão secretarial: uma nova visão de assessoramento nas organizações. Secretariado Executivo em Revista. Passo Fundo, v.6, p. 1-15, 2010. Disponível em: http://www.upf.br/seer/index.php/ser/article/view/2100. Acesso em: 8 mar. 2013.

BICUDO, M. A. V. Pesquisa qualitativa olhada para além dos seus procedimentos. In: BICUDO, M. A. V. (Org). Pesquisa qualitativa segundo a visão fenomenológica. São Paulo: Cortez, 2011.

BÍSCOLI, Fabiana Regina Veloso, CIELO Ivanete Daga. Gestão organizacional e o papel do secretário Executivo. Revista Expectativa, v. 3, n.3, 2004. Disponível em: http://www2.unifap.br/executivo/files/2013/06/10-Gest\%C3\%A3o-secretarial-e-o-papel-dosecretario-executivo.pdf. Acesso em 16 nov 2014.

BRASIL. Lei de Regulamentação da Profissão. Lei no 9261, de 10 de janeiro de 1996. Dispõe sobre o exercício da profissão de secretário e dá outras providências. Disponível em: http://www.fenassec.com.br/b_osecretariado_lei_regulamentacao.html. Acesso em 8 fev. 2014.

Conselho Nacional de Educação. Resolução no 03, de 23 de junho de 2005.

Institui as Diretrizes Curriculares Nacionais para o curso de graduação em Secretariado Executivo e dá outras providências. Disponível em: <http://www.ufv.br/seg/diretrizes/sec.pdf>. Acesso em: 27 fev. 2013.

CABRAL, Augusto Cézar Aquino. Reflexões sobre a pesquisa nos estudos organizacionais :em busca da superação da supremacia dos enfoques organizacionais. In: 
XXII Encontro da ANPAD. Anais... Foz do Iguaçu: Associação Nacional de Pós-Graduação e Pesquisa em Administração, 1998, CD ROM.

CORDEIRO, Roselaine de Lima; GIOTTO, Olivo Thiago. Competências complementares: secretário executivo e administrador. Secretariado Executivo em Revista. Passo Fundo, v. 5, p. 13-27, 2009. Disponível em: http://www.upf.br/seer/index.php/ser/article/view/1776. Acesso em: 9 mar. 2013.

FAYOL, Henri. Administração Industrial e Geral. 10. ed. São Paulo: Atlas, 1990.

FLEURY, Maria Tereza Leme; FLEURY Afonso Fleury. Construindo o conceito de competência. RAC. Curitiba, Edição Especial, p. 183-196, 2001. Disponível em: http://www.scielo.br/scielo.php?script=sci_serial\&pid=1415-6555. Acesso em: 20 jan. 2013.

GRANDO, Caroline. CORREA, S.A.G. RINALDI, N. R. O perfil do Secretário Executivo frente às necessidades das instituições financeiras. Expectativa. Toledo, v.6, n.6, p. 09-64, 2007. Disponível em: http://erevista.unioeste.br/index.php/expectativa/issue/view/171/showToc. Acesso em 19 abr 2011.

GUARIDO FILHO, Edson Ronaldo. MACHADO-DA-SILVA, Clóvis L., GONÇALVES, Sandro Aparecido. Organizational Institutionalism in the Academic Field in Brazil: Social Dynamics and Networks. RAC, Curitiba, Edição Especial 2010, art. 6, p. 149172. Disponível em http://www.scielo.br/pdf/rac/v14nspe/a07v14ns.pdf. Acesso em: 20 jan. 2013.

HOELLER, Patrícia Agostinho Freitas. A natureza do conhecimento em Secretariado Executivo. Revista Expectativa, Paraná, v. 5, n. 5, p. 139-145, 2006. Disponível em: <http://e-revista.unioeste.br/index.php/expectativa/article/viewArticle/89>. Acesso em: 26 set. 2013.

LATTIMORE, Dan; BASKIN, OTIS; HEIMAN, Suzette T.; TOTH, Elizabeth L. Relações públicas: profissão e prática. 3 ed. Porto Alegre: AMGH, 2012.

KÖLLER, Hans-Christoph. Hermeneutik. In: BOHNSACK, Ralf; MAROTZKI, Winfried; MEUSER, Michael (orgs.). Hauptbegriffe Qualitativer Sozialforschung. Ein Wörterbuch. Opladen: Leske u. Budrich (UTB), 2003.

LIMA, Thays Ferreira, CANTAROTTI, Aline. A formação e a construção de competências para a atuação do profissional de Secretariado Executivo: um estudo de caso em uma Empresa Júnior. Revista de Gestão e Secretariado. São Paulo, n. 2, p. 94-122, jul./dez, 2010. Disponível em: http://revistagesec.org.br/ojs-

2.2.4/index.php/secretariado/article/viewArticle/17. Acesso em: 8 mar. 2013. Atlas, 2004.

MAXIMIANO, Antonio Amaru. Introdução à Administração. 6 ed. São Paulo:

MOURA, Maria Alice de. Trabalho e competências em transformação: o papel da profissional de Secretariado. Revista Expectativa. Campos de Toledo, n. 7, p. 27-49. 2008. Disponível em: e-revista.unioeste.br/index.php/expectativa/article/download/.../2046. Acesso em: 8 fev. 2014.

NASCIMENTO, Erivaldo Pereira do. Pesquisa aplicada e interdisciplinaridade: da linguística ao secretariado. In DURANTE, Daniela Giareta (Org). A pesquisa em secretariado: cenário, perspectivas e desafios. Passo Fundo: Ed. Universidade de Passo Fundo, 2012. 
NONATO JÚNIOR, Raimundo. Epistemologia e teoria do conhecimento em secretariado executivo: a fundação das ciências da assessoria. Fortaleza: Expressão Gráfica, 2009.

OLIVEIRA, Luciana Nunes de. MORAES, Glaucia Costa de. O panorama do cargo de secretário executivo em uma instituição federal de ensino superior e as Implicações da lei 11.091/2005. Revista de Gestão e Secretariado - GeSec, São Paulo, v. 5, n. 2, p 49-71, mai./ago. 2014. Disponível em http://www.revistagesec.org.br/ojs-

2.4.5/index.php/secretariado/article/view/250/pdf\#.VGiYETTF9A0. Acesso em 16 nov 2014.

PARASURAMAN, A. Pesquisa de marketing. São Paulo: Atlas, 1991.

PEREIRA , Karen Almeida, SILVA,Manuela Ramos. A atuação do secretário executivo no terceiro setor na cidade de Aracaju. Revista de Gestão e Secretariado - GeSec, São Paulo, v. 5, n. 1, p 104-130, jan./abr. 2014. Disponível em:

file://C:/Documents\%20and\%20Settings/Administrador/Meus\%20documentos/Downloads/2 57-994-1-PB.pdf. Acesso em 16 nov 2014.

PORTELA, Keyla Christina Almeida. SCHUMACHER, Alexandre José. Gestão Secretarial : o desafio da visão holística. Cuiabá: Adeptus, 2009.

QUINN, Robert E. ; FEARMAN, Sue R.; THOMPSON, Michael P.; MCGRATH, Michael. Competências gerenciais: princípios e aplicações. Rio de Janeiro: Elsevier, 2003.

RICHARDSON, Roberto Jarry. Pesquisa social: métodos e técnicas. 3. ed. São Paulo: Atlas, 1999.

ROBBINS, Stephen P.; JUDGE, Timothy A.; SOBAL, Filipe. Comportamento organizacional: teoria e prática no contexto brasileiro. 14. ed. São Paulo: Pearson Prentice Hall, 2010.

SABINO, Rosimeri Ferraz; MARCHELLI, Paulo Sérgio Marchelli. O debate teóricometodológico no campo do secretariado: pluralismos e singularidades. Cadernos EBAPE.BR, n. 4, art. 6, p. 607-621, 2009. Disponível em: http://www.spell.org.br/documentos/ver/1064/o-debate-teorico-metodologico-no-campo-dosecre---. Acesso em: 18 fev. 2014.

SAMPIERI, Roberto Hernández; COLLADO, Carlos Fernández; LUCIO, Pilar Baptista. Metodologia de pesquisa. 3. ed. São Paulo: McGraw-Hill, 2006.

SILVA, Joelma Soares da; BARROS, Conceição de Maria Pinheiro; BARBOSA, Maria Flaviana Silva. Fundamentação da gestão secretarial: um estudo bibliométrico. Revista Gestão e Secretariado, n. 2, p. 106-126, 2012. Disponível em: http://revistagesec.org.br/ojs2.2.4/index.php/secretariado/article/view/114/pdf_14. Acesso em: 9 mar. 2013.

TAGLIARI, Marli de Fátima Carvalho; DURANTE, Daniela Giareta. Gestão Secretarial: semelhanças entre competências gerenciais e secretariais. Secretariado Executivo em Revista. Rio Grande do Sul, v. 5, p. 28-43, 2009. Disponível em: http://www.upf.br/seer/index.php/ser/article/view/1777. Acesso em: 9 mar. 2013.

WOHLRAB-SAHR, Monika. Objektive Hermeneutik. In: Bohnsack, Ralf; Marotzki, Winfried; Meuser, Michael (orgs.). Hauptbegriffe Qualitativer Sozialforschung. Ein Wörterbuch. Opladen: Leske u. Budrich (UTB), 2003, p. 123-128. 